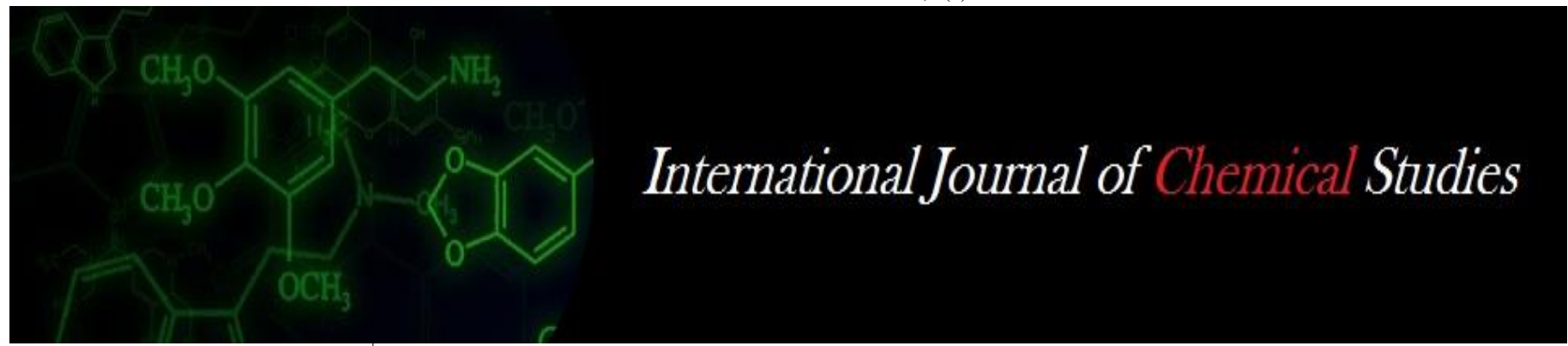

P-ISSN: 2349-8528

E-ISSN: 2321-4902

www.chemijournal.com

IJCS 2020; 8(4): 145-148

(C) 2020 IJCS

Received: 24-05-2020

Accepted: 28-06-2020

\section{YC Lakum}

Department of Agronomy, B.A.

College of Agriculture Anand

Agricultural University, Gujarat,

India

\section{HK Patel}

Department of Agronomy, B.A.

College of Agriculture Anand

Agricultural University, Gujarat,

India

\section{KC Patel}

Department of Agronomy, B.A.

College of Agriculture Anand

Agricultural University, Gujarat, India

\section{GG Patel}

Department of Agronomy, B.A. College of Agriculture Anand Agricultural University, Gujarat, India

\section{PD Patel}

Department of Agronomy, B.A. College of Agriculture Anand Agricultural University, Gujarat, India
Corresponding Author: YC Lakum

Department of Agronomy, B.A. College of Agriculture Anand Agricultural University, Gujarat, India

\section{Effect of organic manures and inorganic fertilizers on maize yield, chemical composition and seed quality under maize: Chickpea cropping sequence}

\author{
YC Lakum, HK Patel, KC Patel, GG Patel and PD Patel
}

DOI: https://doi.org/10.22271/chemi.2020.v8.i4b.9683

\section{Abstract}

The field trial was carried out at College Agronomy Farm, Anand Agricultural University, Anand to study the effects of organic manures and inorganic fertilizers on yield, chemical composition and quality of seed of maize under Maize-Chickpea cropping sequence during the year 2015-17. There were total four organic manure treatments like ( $\mathrm{M}_{1}$ : no manure, $\mathrm{M}_{2}$ : FYM $10 \mathrm{t} / \mathrm{ha}, \mathrm{M}_{3}$ : castor cake $1.0 \mathrm{t} / \mathrm{ha}$ and $\mathrm{M}_{4}$ : vermicompost $2.5 \mathrm{t} / \mathrm{ha}$ ), inorganic fertilizer (like $\mathrm{F}_{1}: 75 \% \mathrm{RDF}$ andF $\mathrm{F}_{2} 100 \% \mathrm{RDF}$ ) and sulphur levels $\left(\mathrm{S}_{1}\right.$ : o kg S/ha and $\mathrm{S}_{2}: 20 \mathrm{~kg} \mathrm{~S} / \mathrm{ha}$ ) with four replications and tested in Randomized Block Design (Factorial). The results indicated that the seed and straw yields were significantly influenced due to combined application of FYM 10 t/ha and 100\% RDF (100-60-00 NPK kg/ha) along with $20 \mathrm{~kg} \mathrm{~S} / \mathrm{ha}$. The nutrients like N, P, K and S content and uptake; chlorophyll content and quality parameter like protein content of maize were also increased due to same set of organic and inorganic fertilizer application.

Keywords: Maize, FYM, castor cake, vermicompost, seed yield, nutrient uptake, chlorophyll

\section{Introduction}

Maize (Zea mays L.) is one of the most important cereal crops in the world agriculture economy both as a food for human being and a feed for animals. There is no cereal on the earth, which has such immense potential like maize and therefore, it occupies the pride place as, "Queen of cereals". Maize is important not only because of its great adaptability to divergent conditions but also due to its high responsiveness to management practices particularly nutrient management. The basic concept underlying used of organic manures and inorganic fertilizer in crop production refers to combining of old and modern methods of nutrient management into ecologically sound and economically optimal farming system. Integrated nutrient management (INM) is a judicious use of organic and inorganic sources of nutrient to crop fields for sustaining and maintaining soil productivity. To counter the detrimental effect of inorganic fertilizers, organic manure are available indigenously which improve soil health resulting enhanced crop yield and quality. Therefore, the trial was conducted to study the effect of nutrient management through sources on maize yield, its chemical composition and seed quality under maize - cowpea cropping sequence.

\section{Materials and Method}

The field experiment was conducted at College Farm, Department of Agronomy, B. A. College of Agriculture, Anand Agricultural University, Anand to study the "Effect of organic manures and inorganic fertilizers on maize yield, chemical composition and seed quality under maize (Zea mays L.) - chickpea (Cicer arietinum L.) cropping sequence" during kharif and rabi seasons of the years 2015-16 and 2016-17. The texture of the soil is loamy sand. The soil is very deep and fairly moisture retentive. The soil of experimental site had low organic carbon $(0.45 \%)$, low available $\mathrm{N}(250.88 \mathrm{~kg} / \mathrm{ha})$, medium available $\mathrm{P}_{2} \mathrm{O}_{5}(48.54 \mathrm{~kg} / \mathrm{ha})$ and $\mathrm{SO}_{4}-\mathrm{S}$ $(15.24 \mathrm{mg} / \mathrm{kg})$; and high available $\mathrm{K}_{2} \mathrm{O}(315.84 \mathrm{~kg} / \mathrm{ha})$. There were total four levels of organic manure like $\left(\mathrm{M}_{1}\right.$ : no manure, $\mathrm{M}_{2}$ : FYM $10 \mathrm{t} / \mathrm{ha}, \mathrm{M}_{3}$ : castor cake $1.0 \mathrm{t} / \mathrm{ha}$ and $\mathrm{M}_{4}$ : vermicompost $2.5 \mathrm{t} / \mathrm{ha})$; two levels of inorganic fertilizer $\left(\mathrm{F}_{1}: 75 \% \mathrm{RDF}\right.$ and $\left.\mathrm{F}_{2}: 100 \% \mathrm{RDF}\right)$ and two sulphur levels $\left(\mathrm{S}_{1}: 0 \mathrm{~kg} \mathrm{~S} / \mathrm{ha}\right.$ and $\left.\mathrm{S}_{2}: 20 \mathrm{~kg} \mathrm{~S} / \mathrm{ha}\right)$. 
The experimental design was Randomized Block Design (Factorial) with four replications. Recommended dose of fertilizer (120-60-0 kg/ha) was applied by urea and DAP chemical fertilizer and sulphur was applied in form of Gypsum to maize crop. All agronomical practices and plant protection measure was followed for better and successful crop production. The observation on yield attributes were recorded by randomly selected five plants from net plot area and tagged all plants for further observations. The seed and straw samples were drawn after harvest of maize and analysed for their nutrient content and quality parameters in laboratory adopting standard procedures. The data of various parameters were statistically analyzed using analysis of variance (ANOVA) technique and the treatments were compared at 5\% levels of significance (Cochran and Cox, 1967) ${ }^{[3]}$.

\section{Results and Discussion}

\section{Effect of organic manure}

Data presented in Table 1 revealed that the application of FYM @ 10t/ha $\left(\mathrm{M}_{2}\right)$ recorded significantly highest seed yield $(4249 \mathrm{~kg} / \mathrm{ha})$ and straw yield $(6420 \mathrm{~kg} / \mathrm{ha})$. The increased in maize yields with the application of organic manure might be due to the availability of both the native and applied nutrients in the soil and substantially enhance their uptake by the plant, leading to overall improvement in the growth and yield attributing characters. Secondly, maximum yield under the treatment of FYM was also attributed to the beneficial effects of FYM by way of regulated liberalization and balanced supply of nutrients, tilting microbial dynamics in favour of the crop growth and creation of salutary soil environmental condition for the crop growth. Similar results were also obtained by Rajkumara et.al (2012) ${ }^{[9]}$, Ashoka et.al. (2013) ${ }^{[2]}$ and Mukherjee (2014) ${ }^{[8]}$ during their investigation.

Data presented in Table 1 indicated that application of FYM @ 10t/ha recorded significantly highest chlorophyll-a (6.83 $\mathrm{mg} / \mathrm{g})$ and chlorophyll-b (1.49 mg/g) content at $30 \mathrm{DAS}$. The increased in chlorophyll contents in leaf under organic manure treatment might be due to significant increase in nutrient availability and water holding capacity of soil which increase plant water potential, which brought out rapid unfolding and expansion of leaf, resulting in increased interception of radiant energy that might have increased synthesis of chlorophyll contents in leaf (Shadded and ElTayeb, 1991) ${ }^{[10]}$.

The significantly highest seed protein content (10.65\%) was recorded under the treatment $\mathrm{M}_{2}$ (FYM @10t/ha) than rest of organic manures treatments. The higher protein content might be due to the protein molecules are presumably built up through controlled condensation of amino acid molecules formed by combining reduced nitrogen with derivative of carbohydrates obtained with the plant system as a product of photosynthesis. Similar result was also reported by Srinivasanarao et al. $(2010)^{[12]}$.

Perusal of results (Tables 2) indicated that the application of FYM @ 10t/ha recorded significantly highest uptake of $\mathrm{N}$ (72.67 kg/ha), $\mathrm{P}_{2} \mathrm{O}_{5}(33.90 \mathrm{~kg} / \mathrm{ha})$, and $\mathrm{K}_{2} \mathrm{O}(18.97 \mathrm{~kg} / \mathrm{ha})$ by seed and 40.87, 21.52 and $42.96 \mathrm{~kg} / \mathrm{ha}$ uptake by straw, respectively, but it was statistically at par with treatment $\mathbf{M}_{4}$ (Vermicompost $2.5 \mathrm{t} / \mathrm{ha}$ ). In case of $\mathrm{S}$ uptake by seed (5.24 $\mathrm{kg} / \mathrm{ha}$ ) was significantly increased due to M2 and at par with M4 treatment but $\mathrm{S}$ uptake by straw (13.76 kg/ha) was significantly increased due to M4 and at par with M2 treatment. This could be attributed to the fact that added organic manures increased the nitrogen, phosphorus, potash and sulphur concentration in seed and straw due to better root establishment, resulting in higher absorption of nutrient to feed and sustain in increased growth lead to higher seed and straw yields. The nutrient uptake is the function of yield and nutrient concentration and yield are more deciding factor for higher nutrient uptake. These findings are in accordance with those reported by Meena et al. (2011) ${ }^{[7]}$.

Table 1: Effect of organic and inorganic fertilizer on seed, straw yields and chlorophyll content of maize (pooled of Two years)

\begin{tabular}{|c|c|c|c|c|}
\hline \multirow{2}{*}{ Treatment } & \multirow{2}{*}{$\begin{array}{c}\text { Seed } \\
\text { yield }\end{array}$} & $\begin{array}{c}\text { Straw } \\
\text { yield } \\
\text { (kg/ha) }\end{array}$ & $\begin{array}{c}\text { Chlorophyll-a } \\
\text { (kg/ha) }\end{array}$ & $\begin{array}{c}\text { Chlorophyll-b } \\
\text { Organic manure (M kg/ha) }\end{array}$ \\
\cline { 3 - 5 } & \multicolumn{5}{|c|}{ At 30 DAS } \\
\hline $\mathrm{M}_{1}$ & 2980 & 4857 & 6.00 & 1.30 \\
\hline $\mathrm{M}_{2}$ & 4249 & 6420 & 6.83 & 1.49 \\
\hline $\mathrm{M}_{3}$ & 4028 & 6136 & 6.46 & 1.41 \\
\hline $\mathrm{M}_{4}$ & 4166 & 6266 & 6.70 & 1.44 \\
\hline S.Em. + & 78.88 & 101.08 & 0.12 & 0.03 \\
\hline C. D. at 5\% & 222 & 284 & 0.34 & 0.08 \\
\hline \multicolumn{5}{|c|}{ Inorganic fertilizer (F kg/ha) } \\
\hline $\mathrm{F}_{1}$ & 3679 & 5705 & 6.30 & 1.37 \\
\hline $\mathrm{F}_{2}$ & 4033 & 6134 & 6.69 & 1.45 \\
\hline S.Em. + & 55.78 & 71.47 & 0.09 & 0.02 \\
\hline C. D. at 5\% & 157 & 201 & 0.24 & 0.05 \\
\hline \multicolumn{5}{|c|}{ Sulphur (S kg/ha) } \\
\hline $\mathrm{S}_{1}$ & 3739 & 5821 & 6.44 & 1.41 \\
\hline $\mathrm{S}_{2}$ & 3973 & 6018 & 6.55 & 1.42 \\
\hline S.Em. + & 55.78 & 71.47 & 0.09 & 0.02 \\
\hline C. D. at 5\% & 157 & $\mathrm{NS}$ & $\mathrm{NS}$ & $\mathrm{NS}$ \\
\hline Interaction & $\mathrm{MxF}$ & $\mathrm{MxF}$ & - & - \\
\hline C. V.\% & 11.57 & 9.66 & 10.65 & 10.87 \\
\hline
\end{tabular}

\section{Effect of inorganic fertilizer}

The treatment $\mathrm{F}_{2}(100 \% \mathrm{RDF})$ was recoded significantly the highest seed yield (4033 kg/ha) and straw yield (6134 kg/ha) over $75 \%$ RDF treatment. The seed yield was increased by $9.6 \%$ and straw yield by $7.5 \%$ due to $\mathrm{F} 1$ over $\mathrm{F}_{2}$ treatment. Application of $100 \%$ RDF recorded significantly the highest seed yield might be due to different levels of RDF was related to the differences in size of photosynthetic surface and to the relative efficiency of total sink activity, possibly a function of number of cobs/ plant, length and girth of cob, average weight/cob and seed index, chlorophyll contents, which in turn influenced the direction of movement of substrates. All these might have cumulatively produced higher seed yield under the $100 \%$ RDF.

The maximum values of chlorophyll-a $(6.69 \mathrm{mg} / \mathrm{g})$ and chlorophyll-b $(1.45 \mathrm{mg} / \mathrm{g})$ contents were registered under the treatment $\mathrm{F}_{2}$ (Tables 1) at 30 DAS. The nitrogen being a structural component of chlorophyll directly helped more synthesis of chlorophyll and increase its content as the recommended dose of fertilizer increased. Secondly, nitrogen has direct involvement in the porphyrin ring structure of chlorophyll molecule. These results are in conformity with the results of Martorana et al. (1997) ${ }^{[6]}$.

Data presented in Table 2 indicated that application of $100 \%$ RDF (F2) noted significantly the highest protein content $(10.43 \%)$. The maize plants had efficiently translocated applied nitrogen and assimilated it into proteinous substances of maize seed.

The significantly the highest uptake of $\mathrm{N}$ by seed and straw ( 67.70 and $38.63 \mathrm{~kg} / \mathrm{ha}$, respectively), $\mathrm{P}_{2} \mathrm{O}_{5}$ by seed and straw (31.77 and $20.51 \mathrm{~kg} / \mathrm{ha}$, respectively), $\mathrm{K}_{2} \mathrm{O}$ by seed and straw (17.82 and (40.42 kg/ha, respectively) and $\mathrm{S}$ by seed and straw (4.79 and $13.12 \mathrm{~kg} / \mathrm{ha}$, respectively) was recorded in treatment $\mathrm{F}_{2}(100 \% \mathrm{RDF})$. The higher uptake values were 
evidently due to higher vegetative growth which might have produced more straw resulting into more uptake.These results are in conformity with the results of Meena et al. (2011) ${ }^{[7]}$ and Kumar and Hiremath (2015) ${ }^{[4]}$.

Table 2: Effect of organic and inorganic fertilizer on protein content and nutrients uptake by maize

\begin{tabular}{|c|c|c|c|c|c|c|c|c|c|}
\hline \multirow[t]{2}{*}{ Treatment } & \multirow{2}{*}{\begin{tabular}{|c|}
$\begin{array}{c}\text { Protein } \\
\text { content }\end{array}$ \\
$(\%)$
\end{tabular}} & \multicolumn{4}{|c|}{\begin{tabular}{|c|} 
Nutrient uptake by \\
seed (kg/ha)
\end{tabular}} & \multicolumn{4}{|c|}{$\begin{array}{l}\text { Nutrient uptake by } \\
\text { Straw (kg/ha) }\end{array}$} \\
\hline & & \begin{tabular}{|l|}
$\mathbf{N}$ \\
\end{tabular} & $\mathbf{P}_{2} \mathrm{O}_{5}$ & $\mathbf{K}_{2} \mathbf{O}$ & $\mathbf{S}$ & $\mathbf{N}$ & $\mathbf{P}_{2} \mathrm{O}_{5}$ & $\mathbf{K}_{2} \mathbf{O}$ & $\mathbf{S}$ \\
\hline \multicolumn{10}{|c|}{ Organic manure $(\mathrm{M})$} \\
\hline & & 4689 & 2281 & 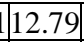 & 3.29 & & & & 9. \\
\hline & & & & & & & & & \\
\hline & & 64. & & & & & & & \\
\hline & & 69. & & & 4.81 & & & & 0.10 \\
\hline & & 1.71 & & & 0.14 & & & 77 & 0.32 \\
\hline & & 4.81 & 2.10 & 1.20 & 0.39 & 2.32 & & 16 & 0.89 \\
\hline \multicolumn{10}{|c|}{ Inorganic fertilizer $(\mathbf{F})$} \\
\hline & & 59.15 & & & & & & & 12.1 \\
\hline & & 67.70 & & & 4.79 & 38. & & & 13.1 \\
\hline & & 1.21 & 3 & 30 & 0.10 & 0.58 & 0.27 & 54 & 0.22 \\
\hline & & 3.40 & 1.49 & 0.85 & 0.28 & 1.64 & 0 & .53 & 0.63 \\
\hline \multicolumn{10}{|c|}{ Sulphur (S) } \\
\hline & & & & & & & & & 12 \\
\hline & & 05.02 & & & 4.83 & 31.11 & & .84 & $413.0 /$ \\
\hline & & 1.21 & 0.53 & 0.30 & 0.10 & 0.58 & 0.27 & .54 & 0.22 \\
\hline & & 3.40 & 1.49 & 0.85 & 0.28 & NS & 0.75 & NS & 0.63 \\
\hline & & $\mathrm{MxF}$ & $\mathrm{MxF}$ & $\mathrm{MxF}$ & $\mathrm{MxF}$ & - & - & $\mathrm{MxF}$ & \\
\hline C. V.\% & 7.92 & 15.27 & 13.99 & 14.31 & 17.41 & 12.61 & 11.00 & 11.07 & 14.1 \\
\hline
\end{tabular}

\section{Effect of sulphur}

The significantly highest seed yield (3973 kg/ha) was recorded with the treatment $S_{2}(20 \mathrm{~kg} \mathrm{~S} / \mathrm{ha})$ over control $\left(S_{1}\right)$. Further, the treatment $S_{2}$ recorded 6.3 per cent higher seed yield over treatment $S_{1}$. These might be due to the fact that sulphur application improved over all nutritional environment of the rhizosphere as well as plant system which could be more advantageous for profuse vegetative and root growth which activated higher absorption of phosphorus, sulphur and nitrogen from the soil and improved metabolic activities inside the plant. Sulphur plays a vital role in the synthesis of chlorophyll, a part of active centre of some enzymes. It also affects various metabolic processes, which ultimately helps in growth and development of plants.

Perusal of data presented in Table 1 indicated that application of sulphur did not showed its effect on Chlorophyll-a $(\mathrm{mg} / \mathrm{g})$ and Chlorophyll-b (mg/g) at 30 DAS, protein content, nitrogen and potash uptake by straw.
Data presented in Table 2 indicated that application of $20 \mathrm{~kg}$ $\mathrm{S} /$ ha $\left(\mathrm{S}_{2}\right)$ was recorded significantly the highest uptake of $\mathrm{N}$ by seed $(65.62 \mathrm{~kg} / \mathrm{ha}), \mathrm{P}_{2} \mathrm{O}_{5}$ by seed and straw (31.15 and $20.00 \mathrm{~kg} / \mathrm{ha}$, respectively), $\mathrm{K}_{2} \mathrm{O}$ by seed $(17.64 \mathrm{~kg} / \mathrm{ha})$ and $\mathrm{S}$ by seed and straw (4.83 and $13.07 \mathrm{~kg} / \mathrm{ha}$, respectively) than treatment $\mathrm{S}_{1}$. The uptake of $\mathrm{N}$ and $\mathrm{K}_{2} \mathrm{O}$ by straw was found non-significant. The beneficial effects of sulphur application to the crop could be more advantageous for profuse vegetative and root growth, which activated higher absorption of $\mathrm{P}$ and $\mathrm{S}$ from soil. Sulphur also reduced alkalinity of soil, which makes plants to absorbed more nutrients i.e. nitrogen and potash from soil. Similar results were obtained by Srinivasanarao et al. (2010) ${ }^{[12]}$.

\section{Interaction effect}

The seed and straw yields were significantly influenced due to interaction effect between organic manure and inorganic fertilizer (Table 3), wherein, treatment combination $\mathrm{M}_{2} \mathrm{~F}_{2}$ recorded highest seed and straw yield (4547 and $6564 \mathrm{~kg} / \mathrm{ha}$ ) The highest seed and straw yield were obtained with the combined use of organic manure and inorganic fertilizer might be due to the fact that yield attributes and cumulative effect of yield attributes mainly responsible for higher productivity. Anup et al. (2010) ${ }^{[1]}$ and Manjhi et al. (2016) ${ }^{[5]}$ were also reported same results.

Data presented Table 3 indicated that treatment combination $\mathrm{M}_{2} \mathrm{~F}_{2}$ exhibited more uptake of $\mathrm{N}(79.54 \mathrm{~kg} / \mathrm{ha}), \mathrm{P}_{2} \mathrm{O}_{5}(36.36$ $\mathrm{kg} / \mathrm{ha}), \mathrm{K}_{2} \mathrm{O}(20.51 \mathrm{~kg} / \mathrm{ha})$ and $\mathrm{S}(5.62 \mathrm{~kg} / \mathrm{ha})$ by seed, but it was statistically at par with treatment combination $\mathrm{M}_{3} \mathrm{~F}_{2}$. Further, highest $\mathrm{K}_{2} \mathrm{O}$ uptake by straw was found with the treatment combination $\mathrm{M}_{2} \mathrm{~F}_{2}(44.15 \mathrm{~kg} / \mathrm{ha})$ followed by treatment combinations $\mathrm{M}_{3} \mathrm{~F}_{2}, \mathrm{M}_{4} \mathrm{~F}_{2}$ and $\mathrm{M}_{2} \mathrm{~F}_{1}$. The higher uptake of $\mathrm{N}, \mathrm{P}, \mathrm{K}$ and $\mathrm{S}$ might be due to better root establishment, resulting in higher absorption of nutrients to feed and sustain in increased growth lead to higher seed and straw yields. The nutrient uptake is the function of yield and nutrient concentration and yield is more deciding factor for higher nutrient uptake. The increased in nutrient uptake might be due to the increase in cation exchange capacity of roots which increased the demand for essential nutrient, resulting from increased biological and economical yield due to application of inorganic fertilizers. Hence, $\mathrm{K}$ uptake was increased with increasing recommended dose of fertilizer in conjunction with organic manure. These results are akin to those reported by Rajkumara et al. (2012) ${ }^{[9]}$ and Mukherjee $(2014)^{[8]}$.

Table 3: Interaction effect of organic manures and inorganic fertilizer on seed, straw yield and nutrient content in eed and potash content in straw

\begin{tabular}{|c|c|c|c|c|c|c|c|c|c|c|c|c|c|c|}
\hline \multirow{3}{*}{$\begin{array}{c}\text { Organic } \\
\text { manure }(\mathbf{M})\end{array}$} & \multicolumn{14}{|c|}{ Inorganic fertilizer $(\mathbf{F})$} \\
\hline & \multicolumn{2}{|c|}{$\begin{array}{c}\text { Seed yield } \\
\text { (kg/ha) }\end{array}$} & \multicolumn{2}{|c|}{$\begin{array}{c}\text { Straw yield } \\
(\mathrm{kg} / \mathrm{ha})\end{array}$} & \multicolumn{2}{|c|}{$\begin{array}{c}\text { N uptake by seed } \\
(\mathrm{kg} / \mathrm{ha})\end{array}$} & \multicolumn{2}{|c|}{$\begin{array}{c}\text { P uptake by seed } \\
(\mathrm{kg} / \mathrm{ha})\end{array}$} & \multicolumn{2}{|c|}{$\begin{array}{c}\mathrm{K}_{2} \mathrm{O} \text { uptake by } \\
\text { seed }(\mathrm{kg} / \mathrm{ha})\end{array}$} & \multicolumn{2}{|c|}{$\begin{array}{l}\text { S uptake by } \\
\text { seed (kg/ha) }\end{array}$} & \multicolumn{2}{|c|}{$\begin{array}{c}\mathrm{K}_{2} \mathrm{O} \text { uptake by } \\
\text { straw(kg/ha) }\end{array}$} \\
\hline & $\mathrm{F}_{1}$ & $\mathrm{~F}_{2}$ & $\mathrm{~F}_{1}$ & $\mathrm{~F}_{2}$ & $\mathrm{~F}_{1}$ & $\mathrm{~F}_{2}$ & $\mathrm{~F}_{1}$ & $\mathrm{~F}_{2}$ & $\mathrm{~F}_{1}$ & $\mathrm{~F}_{2}$ & $\mathrm{~F}_{1}$ & $\mathrm{~F}_{2}$ & $\mathrm{~F}_{1}$ & $\mathrm{~F}_{2}$ \\
\hline $\mathrm{M}_{1}$ & 2870 & 3091 & 4592 & 5122 & 44.36 & 49.41 & 21.70 & 23.93 & 12.36 & 13.22 & 3.14 & 3.44 & 29.35 & 33.64 \\
\hline $\mathrm{M}_{2}$ & 3952 & 4547 & 6492 & 6564 & 65.79 & 79.54 & 31.45 & 36.36 & 17.42 & 20.51 & 4.87 & 5.62 & 41.77 & 44.15 \\
\hline $\mathrm{M}_{3}$ & 3668 & 4388 & 5708 & 6348 & 57.45 & 72.28 & 28.67 & 34.23 & 15.88 & 19.52 & 4.28 & 5.33 & 38.45 & 42.74 \\
\hline $\mathrm{M}_{4}$ & 4107 & 4225 & 6029 & 6504 & 69.02 & 69.55 & 32.89 & 32.56 & 18.57 & 18.02 & 4.85 & 4.77 & 40.04 & 43.53 \\
\hline S.Em. + & \multicolumn{2}{|c|}{111.5} & \multicolumn{2}{|c|}{142.9} & \multicolumn{2}{|c|}{2.42} & \multicolumn{2}{|c|}{1.05} & \multicolumn{2}{|c|}{0.61} & \multicolumn{2}{|c|}{0.20} & \multicolumn{2}{|c|}{1.09} \\
\hline 0C. D. at $5 \%$ & \multicolumn{2}{|c|}{313} & \multicolumn{2}{|c|}{401} & \multicolumn{2}{|c|}{6.80} & \multicolumn{2}{|c|}{2.97} & \multicolumn{2}{|c|}{1.70} & \multicolumn{2}{|c|}{0.55} & \multicolumn{2}{|c|}{3.05} \\
\hline
\end{tabular}

\section{Conclusion}

The overall results can be concluded that the application of FYM @ 10t/ha with 100\% Recommended Dose of fertilizer (120-60-0 NPK kg/ha) and $20 \mathrm{~kg}$ S/ha gave highest seed and straw yield of maize. The nutrients like N, P, K and S content and uptake and quality parameter like protein content of maize were also increased due to same set of organic and inorganic fertilizer application. 


\section{Acknowledgement}

Authors are very much thankful to the Director of Research and Dean P.G. Studies, Principal and Dean, B. A. College of Agriculture and Professor and Head, Department of Agronomy and my guide for valuable suggestions and support to conduct the research program and obtain its significant findings.

\section{References}

1. Anup D, Patel DP, Munda GC, Ghosh PK. Effect of organic and inorganic sources of nutrients on yield, nutrient uptake and soil fertility of maize (Zea mays)mustard (Brassica campestris) cropping system. Indian J Agril. Sci. 2010; 80(1):85-88.

2. Ashoka P, Khot BA, Neelkanth JK. Integrated nutrient management in maize-bengal gram cropping system in vertisols. Environment \& Ecology. 2013; 31(3):13371340.

3. Cochran WG, Cox GM. Experimental designs, John Willey and Sons. Inc., New York, 1957, 546-568.

4. Hiremath SM, Mohankumar R, Gaddi A. Influence of balanced nutrition on productivity, economics and nutrient uptake of hybrid maize- chickpea cropping sequence under irrigated ecosystem. Indian J Agron. 2016; 61(3):292-296.

5. Manjhi RP, Mahapatra P, Shabnam S, Yadava MS. Long term effect of nutrient management practices on performance of quality protein maize under maize- wheat cropping sequence. Indian J Agron. 2016; 61(4):436-442.

6. Martorana F, Bellocchi G, Mariotti M. Effect of nitrogen fertilizer application on light interception by maize (Zea mays L.). Rivista di Agronomia. 1997; 31(3):585-589.

7. Meena KN, Kumar A, Rana DS, Meena MC. Productivity and nutrient uptake of maize- wheat cropping system under different bio- sources and nitrogen levels. Indian J Agron. 2011; 56(3):182-188.

8. Mukherjee D. Influence of integrated nutrient management on productivity, nutrient uptake and economics of maize-yellow sarson cropping system under rainfed mid hill condition. Indian J Agron. 2014; 59(2):221-228.

9. Rajkumara S, Gundlur SS, Khot AB. Effect of continuous application of organics to supply nitrogen and phosphorus on maize and chickpea under irrigated condition. Indian J agril. Sci. 2012; 82(10):892-895.

10. Shadded MA, El-Tayeb MA. Interactive effects of soil moisture content and hormonal treatment on dry matter and pigment contents of some crop plants. Crop Physiol. Abstr. 1991; 17(1):41.

11. Shahid I, Christian T, Khan HZ, Javeed HMR, Arif M, Shehzad M et al. Maximizing maize quality, productivity and profitability through a combined use of compost and nitrogen fertilizer in a semi-arid environment in Pakistan. Nutr Cycl Agroecosyst. 2017; 107:197-213.

12. Srinivasanarao, Massod Ali, Venkateswarlu S, Rupa TR, Singh KK, Kundu S et al. Direct and residual effect of integrated sulphur fertilization in maize- chickpea cropping system on Typicustochrept. Indian $\mathrm{J}$ Agron. 2010; 55(4):259-263. 